\title{
Pharmaciana
}

Vol.10, No.3, Nov 2020, Page. 239-248

ISSN: 2088 4559; e-ISSN: 24770256

\section{Antiproliferation activity of water and ethyl acetate red yeast rice fraction against MCM-B2 tumor cells}

\author{
Hasim Hasim ${ }^{* 1}$, Surya Pangidoan Nasution ${ }^{1}$, Bambang Pontjo Priosoeryanto ${ }^{2}$, \\ Eka Nurul Qomaliyah ${ }^{1}$ \\ ${ }^{I}$ Department of Biochemistry, Faculty of Mathematics and Natural Sciences, IPB University \\ Jl. Tanjung, Dramaga, Bogor West Java, Indonesia \\ ${ }^{2}$ Department of Veterinary Clinic Reproduction and Pathology, Faculty of Veterinary Medicine, \\ IPB University \\ Jl. Agatis, Dramaga ,Bogor, West Java, Indonesia
}

Submitted: 13-06-2020

Reviewed: 01-07-2020

Accepted: 12-10-2020

\begin{abstract}
Red yeast rice (RYR), commonly known as angkak, is a functional food fermented by rice using Monascus mushrooms. It has a pigment and flavonoid content that is useful as an antioxidant and plays a role in preventing cancer or tumors. This analysis aims to test the antiproliferation activity of commercial RYR fractions of water and ethyl acetate against Miyazaki Canine Mammary Gland Tumor-Bambang 2 (MCM-B2) breast tumor cells. Research on RYR antiproliferation of cancersustaining MCM-B2 cells has not been previously released. In the preliminary study, the antiproliferation bioactivity was measured using the brine shrimp lethality test. The outcome of the brine shrimp lethality test showed that ethyl acetate and water fraction cytotoxicity were more than $1000 \mathrm{ppm}$ and $337.07 \mathrm{ppm}$, respectively, at a lethal concentration of 50. Antiproliferative activity analyses were performed using direct hemocytometer counting. The antiproliferation activity data collected were analyzed using one-way ANOVA and Duncan continuous testing. The outcome showed that the water and ethyl acetate RYR antiproliferation activity against MCM B2 cancer cells correlated positively with the increasing concentration of each fraction. Ethyl acetate and water fractions at concentrations of $350 \mathrm{ppm}$ may inhibit the growth of MCM-B2 cancer cells in vitro, reaching 42.63 percent and 39.84 percent, respectively, not significantly different $(\mathrm{P}<0.05)$ with a positive doxorubicin control of 41.24 percent. In conclusion, the ethyl acetate and water fraction of RYR have potent antiproliferation activity against MCM-B2 breast tumor cells.
\end{abstract}

Keywords: antiproliferation, direct counting, MCM-B2 cell, red yeast rice

\footnotetext{
*Corresponding author:

Hasim

Department of Biochemistry

Faculty of Mathematics and Natural Science

IPB University

J1. Tanjung, Dramaga, Bogor West Java, Indonesia

Email: hasim@apps.ipb.ac.id
} 


\section{INTRODUCTION}

The second leading death rate for women globally is breast cancer (Liu and Chen, 2013; Park et al., 2005). The World Health Organization (WHO) announced that an estimated 627,000 women died of breast cancer, approximately 15\% of all cancer deaths among women in 2018 (WHO, 2020). Birth cancer, including radiation, exposure to chemicals with carcinogenic effects, viruses, carcinogenic food intakes, and a lack of consumption of fruits and vegetables, are factors which cause abnormality proliferation of the cell in the body. The creation of abnormal lumps begins with breast cancer, called tumors. One form of breast tumor cell may be isolated from the mammary glands of a 10-year-old female dog (MCM-B2). These tumor cells are formed from atypical cells and stem cells (Priosoeryanto et al., 1995). Natural products, particularly in the field of cancer pharmacology, had long played an essential role in drug discovery. RYR is an anticancer alleged secondary metabolite and pigment of the source.

$\mathrm{RYR}$ is a rice-derived product that ferments rice using Monascus sp. mushrooms. In Asian society, RYR has become a popular supplement to food, herbal products, and health (Lee et al., 2013). RYR is a commercial market in Asia, including Indonesia. It includes food additives, preservatives, food coloring in fish, and meat (Wei et al., 2003). RYR also acts as a fruit flavor enhancer for yogurt except as a coloring agent. Alternative food coloring and pigments were developed by RYR (Dweck, 2002). As a traditional medicine, RYR also strengthens the digestive system, accelerates blood circulation, reinforces the spleen function and dries the wound into the stomach area (Nijjar et al., 2010; Yang et al., 2014). Monascus pigment demonstrates pro-apoptosis effects or the ability to inhibit the growth of various types of tumor cells (Lee et al., 2013). Recent experiments have found Manocalin K, an active metabolite of RYR, as competitive with HMG-CoA Reductase, which can inhibit cholesterol biosynthesis (Zhang et al., 2016). RYR also contains saponins, triterpenoids, terpenoids, coumarin, flobatin and flavonoids. The possible antioxidant of all of these metabolites. Food with antioxidants helps the body process the proliferation of lymphocytic cells, which can lyses cancer cells from natural killers (Agustinisari and Zakaria, 2019).

Pigments and other compounds in RYR have contributed to antiproliferative effects (Hong et al., 2011). Recent studies have shown that RYR pigment inhibits skin cancer (Hsu and Pan, 2012), tumor growth in mice; c67 BL pulmonary carcinoma is inhibited (Ho and Tzu-Ming, 2009). The use of RYR metabolites as a new approach to cancer prevention and treatment may be expected, but further verification remains important in preclinical and clinical studies. A naturally occurring compound can be named anticancer as anticancer, antiproliferation with different types of cancer cells has been reported in several studies. Flavonoid has a secondary anticancer potential in addition to the pigment present in RYR (Lee et al., 2013). RYR antiproliferation activity has not been identified in Miyazaki Canine Mammary Gland Tumor-Bambang 2 (MCM-B2) breast tumor cells. Since each cell varies in its sensitivity and mechanism from the natural product, MCM-B2 can be generated from atypical stem cells or cells (Priosoeryanto et al., 1995). Observation in vitro of the MCMB2 cell line shows that these cells exhibit homogeneous morphological and immunohistochemistry characteristics and also display less differentiation in cell culture, with this characteristic of the MCM-B2 cell being clearly capable of inhibiting the spread, but with a low potential of the natural product (Elsyana et al., 2016), as expected in commercial RYR used in this study.

The purpose of this analysis is to test the antiproliferation activity of commercial RYR fractions of water and ethyl acetate against MCM-B2 breast tumor cells. The use of water and ethyl acetate as fractional solvents has polar and semipolar solvent characteristics that can be optimally used as anticancer properties for the extraction of pigmentation components and secondary compounds.

Pharmaciana Vol. 10, No. 3, Nov 2020, Page. 239-248 


\section{MATERIALS AND METHOD \\ Materials}

In this study, Mean material RYR was collected from the traditional market in Bogor, West Java. Besides, MCM B-2 tumor cells were collected from the tissue culture collection of Faculty Veterinary Medicine, IPB University.

\section{Methods}

\section{Preparation of water and ethyl acetate fraction of red mold rice}

Sample preparation, extraction, and fractionation were carried out based on the previous study with modification (Hasim et al., 2017). Samples of commercial RYR were dried for 6 hours in an oven at $50^{\circ} \mathrm{C}$. In addition, the blender has been mashed to 40 mesh scale. The moisture content of the sample to be used is < 10 percent. Maceration and removal with 96 percent ethanol up to $800 \mathrm{~mL}$ with $110 \mathrm{rpm}$ shaker is used to extract 40 grams of RYR. The filter was evaporated with a $50^{\circ} \mathrm{C}$ rotating evaporator. Fractionation is done with water and ethyl acetate as a solvent using the liquid-liquid partition process. A rotary evaporator at a temperature of $50^{\circ} \mathrm{C}$ was used for a fraction of ethyl acetate and water.

\section{Brine Shrimp Lethality Test (BSLT)}

The BSLT test was performed to determine the range of concentrations that would then be used to evaluate the antiproliferation test. BSLT tests were carried out using the (Rampe and Tombuku, 2015) method with modification. A steady supply of oxygen has been in the artemia salina shrimming larvae for 48 hours. Dissolving the ethyl acetate and water fraction of RYR with seawater in order to produce test stock solutions with a concentration of $2000 \mu \mathrm{g} / \mathrm{mL}$ was performed. The stock solution has been diluted in a plate using sea waters to measure levels of $0,100,200,400,600,800$, and 1000 $\mu \mathrm{g} / \mathrm{mL}$. After 24-hour incubation, dead shrimp larvae have been counted and LC50 values have been determined. The test was conducted with a triplicate.

\section{Antiproliferation activity}

Tumor cell inhibitory activity test was performed using Priosoeryanto et al. (Priosoeryanto, 2009), Starting by planting MCM-B2 cells using DMEM media on a 24-well tissue plate. The planting media contained $850 \mu \mathrm{L}$ of growth media, $10 \mu \mathrm{L}$ of fungizone, $10 \mu \mathrm{L}$ of gentamicin and $30 \mu \mathrm{L}$ of serum. Water fraction and ethyl acetate fraction were weighed at $0.02 \mathrm{~g}$ to be liquefied in $10 \mathrm{~mL}$ of sterile distilled water. The extract doses used were 87.5, 175, 350, 700 and $1400 \mu \mathrm{g} / \mathrm{mL}$ (as defined by BSLT LC50). In addition, first thawing treatment is given to the cell suspension. MCM-B2 Sustainable Cell Suspension Plate up to $50 \mu \mathrm{L}$ per hole. Wells that have not been applied to the fraction as a negative control $(0 \mathrm{ppm})$ and wells that have been applied to $100 \mu \mathrm{g} / \mathrm{mL}$ of doxorubicin as a positive control. MCM-B2 sustainable cells were grown by incubation at $37^{\circ} \mathrm{C}\left(5 \% \mathrm{CO}_{2}\right)$ in the incubator for 3 days.

The tumor cell inhibitory activity test is conducted by cell harvesting and counting. Sustainable cell harvesting is carried out when the negative control has expanded optimally to cover about $70 \%$ of the entire surface after 3 days of planting. The cell suspension is then homogenized by up and down pipetting using a micropipette. Next, $80 \mu \mathrm{L}$ cells were injected into a $20 \mu 1$ trypan blue dye microplate. The homogeneous cell suspension was dropped on the hemacytometer of Neubauer. The number of cells was counted with a light microscope. The cells that are counted are living and dead cells in the center of the measured space. This test was performed with a triplicate. 


\section{Data analysis}

Probit analysis was performed using MINITAB 17 as BSLT data to assess the 50 percent mortality concentration (LC50) at 95 percent confidence intervals. Data on antiproliferation behavior were analyzed using variance analysis ( ANOVA) by Duncan 's continued P $\leq 0.05$ test to identify the significance of differences between treatment and control groups.

\section{RESULT AND DISCUSSION}

In this analysis, the extraction of RYR was performed using maceration and remaceration dynamically, with $96 \%$ ethanol. The advantages of using $96 \%$ ethanol as a solvent is nontoxic, noncorrosive, has a strong absorption rate, require only a little heat in the evaporation process and is readily available (Lestari, 2015). Ethanol is a polar solvent and has a lower polarity than water, so it can attract polar and semipolar compounds in RYR simplicia.

Recent studies have recorded that ethanol extract and ethyl acetate fraction of RYR contain flavonoid: 8.84 and $22.09 \mathrm{mg}$ QE/g RYR simplicia, respectively (Hasim et al., 2017). Another research reported that pigments in RYR are yellow pigment (monascin, ankaflavin), pink pigment (monascurbin, ribropunctamine) (Pattanagul et al., 2007). The pigment contains flavonoid anthocyanin, which makes RYR a potentially anticancer. Increasing epidemiological studies indicate that high intake of flavonoids could be associated with a decreased risk of cancer (Batra and Sharma, 2013). In addition, active anticancer compounds such as manocalin $K$ would increase with an increase in the ethanol concentration used for extraction (Singgih et al., 2014).

Meanwhile, fractionation was conducted using two separate polarity solvents. Pigmentcontaining anthocyanin has a polar structure that makes them dissolve easily in polar and semipolar solvents. This research, therefore, uses ethyl acetate as a semipolar solvent and water as a polar solvent. The difference in the degree of polarity and the specific gravity of each solvent is the concept of separation of the compounds in the sample used (Pratiwi et al., 2016). The fractionation outcomes showed that water has a higher yield compared to ethyl acetate fractions, as shown in Figure 1. These data indicate that the fraction of water has a higher yield than the fraction of ethyl acetate. Water and ethyl acetate fractions yield $18.80 \pm 0.29$ and $11.58 \pm 0.64 \%$, respectively. It can be indicated that the RYR used in this analysis has more polar metabolites.

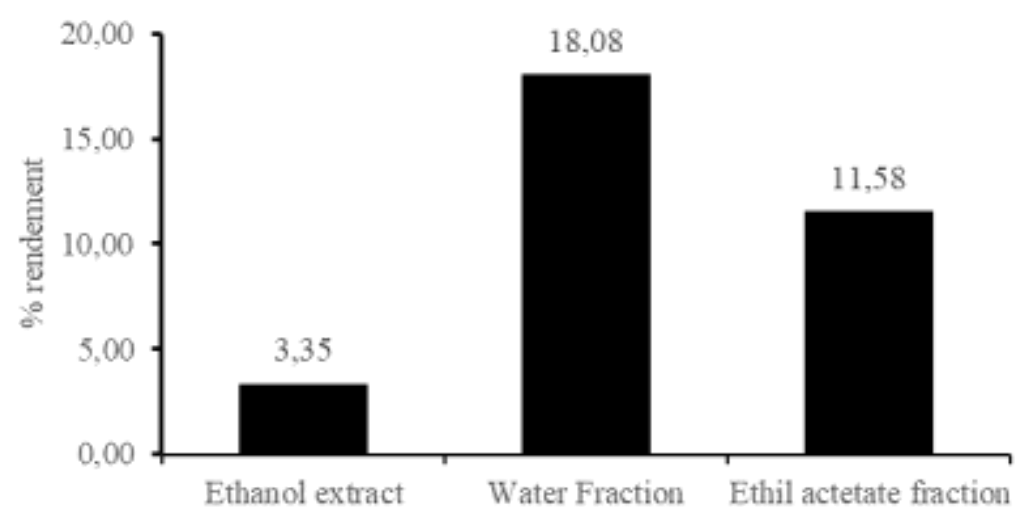

Figure 1. \% Yield extraction of red yeast rice

Pharmaciana Vol. 10, No. 3, Nov 2020, Page. 239-248 
The BSLT was used as an initial measure of RYR antiproliferation activity. The parameter calculated was the mortality rate of Artemia salina shrimp larvae in the nauplii process after a red yeast rice fraction sample. Death of Artemia salina larvae is correlated with the potential of bioactive compounds in the sample with the reduced anti-inflammatory activity of larvae (Vitalia et al., 2016). Flavonoid compounds can cause the death of Artemia salina larvae through the gastric poisoning mechanism of larval death by inhibition of food inhibition (antifedant) (Vitalia et al., 2016). Based on Meyer's toxicity index, a sample was reported to have a potential for bioactivity if it had an LC50 value (50\% mortality rate for Artemia salina shrimp larvae) of $<1000 \mu \mathrm{g} / \mathrm{mL}$ (R. Hamidi et al., 2014). Based on this categorization, the RYR water fraction in this study included anticancer activity as a bioactivity potential. While the fraction of ethyl acetate has a value of LC50 $>1000 \mu \mathrm{g} / \mathrm{mL}$. The BSLT test results show that the more polar solvent (water), the more toxic the effect. The results of the BSLT test are shown in Tables 1 and 2. These data indicate that ethyl acetate and water fractions have values of LC50 > $1000 \mathrm{ppm}$ and $337.07 \mathrm{ppm}$, respectively. The LC50 BSLT value of the $337.07 \mathrm{ppm}$ rounding water fraction to $350 \mathrm{ppm}$ was invented as a mean value to assess the concentration range in the antiproliferation analysis. Thus, the LC50 values obtained from the cytotoxic pre-screening test of Artemia salina larvae provide a picture of RYR extract with potential bioactivity, including an anticancer compound, for further testing of MCM-B2 breast cancer cells in vitro.

Table 1. The BSLT test result of Red yeast rice

\begin{tabular}{ccc}
\hline Fraction & Concentration $(\mathbf{p p m})$ & $\begin{array}{c}\text { \% } \\
\text { mortality of } \\
\text { cell }\end{array}$ \\
\hline Water & 100 & 36.7 \\
& 200 & 50 \\
400 & 66.7 \\
& 800 & 80 \\
& 1000 & 96.7 \\
Ethyl acetate & 2000 & 10 \\
& 100 & 0 \\
& 200 & 0 \\
& 400 & 0 \\
& 800 & 0 \\
& 1000 & 0 \\
& 2000 & 40 \\
\hline
\end{tabular}

Table 2. $\mathrm{LC}_{50}$ of water and ethyl acetate fraction of red yeast rice using BSLT methods

\begin{tabular}{ll}
\hline Sample (fractions) & $\mathbf{L C}_{\mathbf{5 0}}(\mathbf{p p m})$ \\
\hline Ethyl acetate & $>1000$ \\
Water & 337.07 \\
\hline
\end{tabular}

The antiproliferation study of both water and ethyl acetate fractions showed that MCM-B2 cancer cell proliferation decreased with increasing concentration. The variation of fraction concentration of the antiproliferation test was based on the outcome of the LC50 of BSLT test. A negative control containing only culture media and MCM-B2 cells was considered to have a proliferation activity of 100 percent and an antiproliferation activity of 0 percent. A positive control containing $100 \mathrm{ppm}$ cancer drug (doxorubicin), DMEM rising media and MCM-B2 cells are considered to have an antiproliferation effect of $41.24 \%$. Doxorubicin has been used as a proactive 
antiproliferation regulation in MCM-B2 cells (Djamaludin et al., 2019). Doxorubicin is used as an anthracycline synthesis drug in cancer patients for chemotherapy (Yun et al., 2019). Two proposed mechanisms of doxorubicin act in cancer cells, i.e. DNA intercalation and topoisomerase-II-mediated DNA repair and free radical generation and damage to cell membranes, DNA, and proteins (Thorn et al., 2011). However, doxorubicin can cause many side effects such as hair loss, nausea, dry lips, vomiting, and heart problems (Atiqoh et al., 2011; Hasim et al., 2020).

Average inhibition of MCM-B2 ethyl acetate cancer cells and the water fraction of RYR is expressed as a percentage of antiproliferation. Based on the graphs shown in Figures 2 and 3. These findings indicate that the distribution of MCM-B2 cancer cells decreases with increasing concentration. The antiproliferation test results show that concentration of $350 \mu \mathrm{g} / \mathrm{ml}$, the antiproliferation activity of the water fraction and the ethyl acetate fraction did not have a significant difference with doxorubicin as a positive control. In general, the fraction of ethyl acetate will reduce MCM-B2 cells proliferation.

The fraction of $350 \mathrm{ppm}$ ethyl acetate has an antiproliferation activity of $42.63 \%$ greater than $100 \mathrm{ppm}$ doxorubicin and has no significant difference through the Duncant test. The higher the concentration of ethyl acetate fraction used, the higher the antiproliferation activity.

The water fraction antiproliferation activity is shown in Figure 3. Water fractions, in general, can reduce the proliferation of MCM-B2 cells. Water fraction $350 \mathrm{ppm}$ has an antiproliferation activity $39.84 \%$ lower than the antiproliferation activity of $100 \mathrm{ppm}$ doxorubicin $41.24 \%$ but has no substantial difference from the Duncant test. The higher the concentration of the water fraction used, the greater the antiproliferation activity.

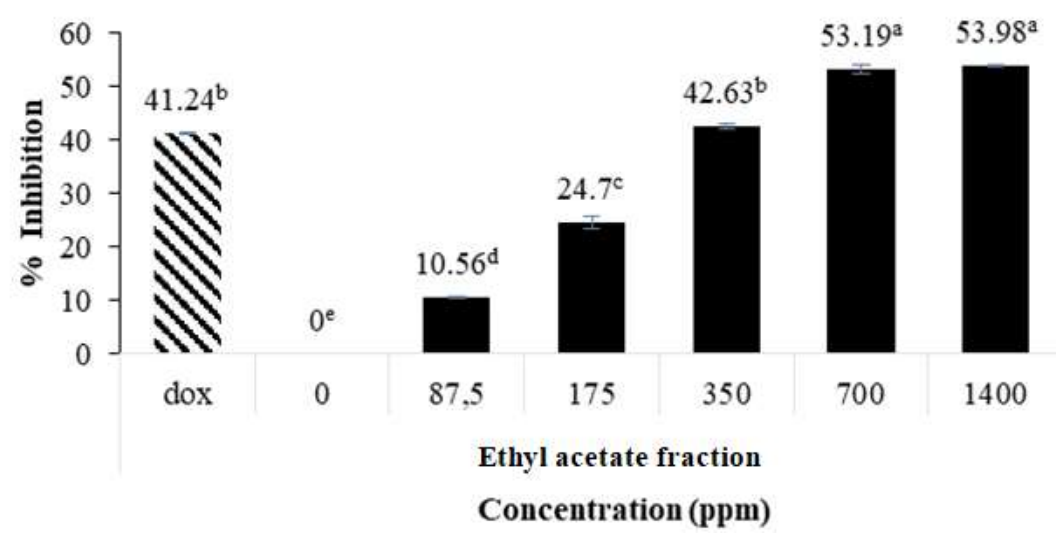

Figure 2. Antiproliferation activity of ethyl acetate fraction against MCM-B2 cells Each data represent the mean of triplicate inhibition percentage. Values followed with different superscripts (a, b, c, d and e) represent significant differences at p $<0.05$. a showed the highest inhibition potential, while e showed the lowest inhibition

Pharmaciana Vol. 10, No. 3, Nov 2020, Page. 239-248 


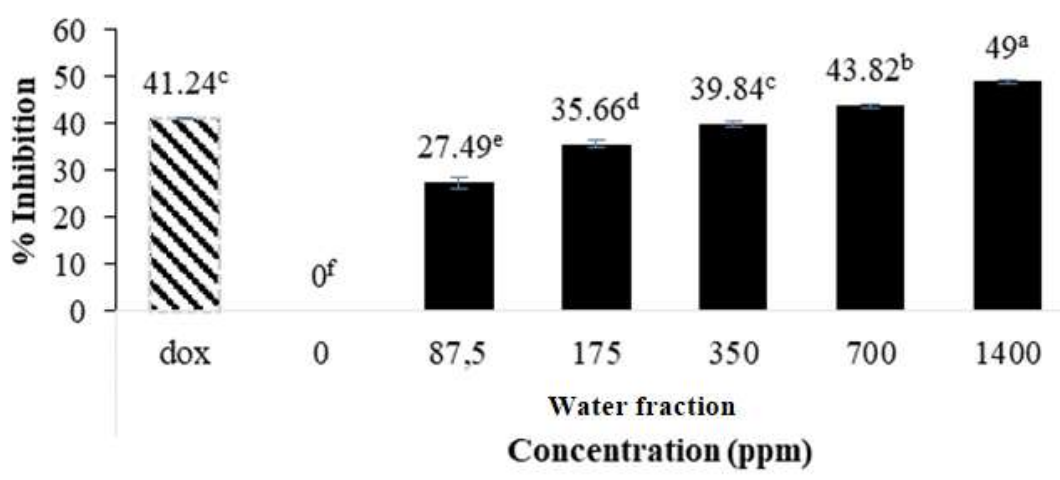

Figure 3. Antiproliferation activity of water fraction of red yeast rice against MCM-B2 cells Each data represents the mean of triplicate inhibition percentage. Values followed with different superscripts (a, b, c, d, e, and f ) represent significant differences at $\mathbf{p}<0.0$. a showed the highest inhibition, while $f$ showed the lowest inhibition

The antiproliferation activity of ethyl acetate fraction increased more with an increase in concentration than the water fraction. This is confirmed by the findings of previous studies that the RYR fraction of ethyl acetate contains more phenolic and flavonoid compounds than the water extract (Hasim et al., 2017). Further research on the identification of flavonoid compounds acting as anticancer in this RYR is required. The difference in the antiproliferative activity of the above fraction may be due to variations in the response or sensitivity of the cancer cell receptor MCM-B2 to each of the active compounds in each fraction (Talib and Mahasneh, 2010). Since the LC50 value, the fraction of ethyl acetate is classified as nontoxic to Artemia salina, but the results of the MCM-B2 cell tests can inhibit cell growth. The explanation for this is that the MCM-B2 cells used are cells that have not been differentiated. They are, after all, stem cell origin (Priosoeryanto, 2009). Therefore, cell growth is interrupted when given a sample of the ethyl-acetate fraction. Although the test object used in BSLT is an organism that has been differentiated (limbs are complete) and the digestive tract is perfect (Muaja, 2013). As the consequence, concentrations of less than or equal to $1,000 \mathrm{ppm}$ can not kill half of the total population of shrimp larvae.

Previous in vitro experimental analysis of RYR aqueous and ethanol extract demonstrated inhibitory activity in pre-adipocyte proliferation (Bule et al., 2018). RYR anticancer plays a role as antiproliferation by programmatic induction of cell death (apoptosis), based on preclinical in vivo studies, it is established that one of the red pigments (rubropuncatin) of RYR contains anthochyanin flavonoid, induce apoptosis (Zheng et al., 2010). RYR contains monacalin K, phenolic and flavonoids which are useful for regulating the growth of cancer cells. RYR consists of rubropunctantin and manocaline, which has a very powerful anticancer activity against cancer cells (Xu et al., 2017). In addition, flavonoids function by three mechanisms to stimulate the apoptotic pathway in cancer cells by acting as an oxidant, the second inhibit protein kinase activity that induces signal transduction inhibition, and the third inhibits tyrosine kinase receptor activity that increases and plays a role in the growth of cancer cell malignancy (Mardany et al., 2016). In addition, the mechanism of flavonoids as anticancer is the inactivation of carcinogens, antiproliferation, suppression of the cell cycle, induction of apoptosis, differentiation, and inhibition of angiogenesis (Ismaryani et al., 2018). Further analysis of flavonoid structure as secondary metabolites with anticancer properties in both the water and ethyl acetate fractions of this RYR is required. 


\section{CONCLUSION}

Water and ethyl acetate fraction of ethanol extract of red yeast rice have been shown to have antiproliferation activity against MCM-B2 cells. The fraction of ethyl acetate has greater antiproliferation activity compared to the fraction of water.

\section{ACKNOWLEDGEMENT}

The authors would like to thank all of the laboratory staff of veterinary reproduction and pathology and laboratory staff of biochemistry for their assistance during this study.

\section{REFERENCES}

Agustinisari, \& Zakaria. (2019). Pengaruh ekstrak rimpang jahe (Zingiber officinale Roscoe). Jurnal Penelitian Pascapanen Pertanian, 3(1), 50-59.

Atiqoh, H., Wardani, R. S., \& Wulandari, M. (2011). Uji antidiabetik infusa kelopak bunga rosella (Hibiscus sabdariffa Linn.) pada tikus putih jantan galur wistar yang diinduksi glukosa. Jurnal.Unimus.Ac.Id 4, 7(1), 43-50.

Batra, P., \& Sharma, A. K. (2013). Anticancer potential of flavonoids: recent trends and future perspectives. 3 Biotech, 3(6), 439-459. https://doi.org/10.1007/s13205-013-0117-5

Bule, M., Khan, F., \& Niaz, K. (2018). Red Yeast Rice (Monascus purpureus). In Nonvitamin and Nonmineral Nutritional Supplements. Elsevier Inc. https://doi.org/10.1016/B978-0-12-8124918.00067-9

Djamaludin, H., Bintang, M., \& Priosoeryanto, B. P. (2019). Cytotoxicity and antiproliferative effects of ethyl acetate fraction of padina australis against MCM-B2 and K562 cell lines. Journal of Applied Biology and Biotechnology, 7(2), 25-29. https://doi.org/10.7324/JABB.2019.70205

Dweck, A. C. (2002). Natural ingredients for colouring and styling. International Journal of Cosmetic Science, 24(5), 287-302. https://doi.org/10.1046/j.1467-2494.2002.00148.x

Elsyana, V., Bintang, M., \& Priosoeryanto, B. P. (2016). Cytotoxicity and antiproliferative activity assay of clove mistletoe (Dendrophthoe pentandra (L.) Miq.) leaves extracts. Advances in Pharmacological Sciences, 2016. https://doi.org/10.1155/2016/3242698

Hasim, Andrianto, D., Ismail, A., \& Faridah, D. (2017). Antioxidant and $\alpha$-Glucosidase inhibitory activity of formulated ethanol extract of red yeast rice and rice bran. Journal of Pharmacognosy and Phytochemistry, 6(5), 1891-1893.

Hasim, H., Kurniawati, S. O., Priosoeryanto, B. P., Faridah, D. N., \& Puspita, R. (2020). Antiproliferation activity of God's crown fruit (Phaleria macrocarpa) extract and fractions against MCM-B2 breast cancer cells. Journal of Applied Pharmaceutical Science, 10(3), 52-58. https://doi.org/10.7324/JAPS.2020.103006

Ho, B. Y., \& Tzu-Ming, P. A. N. (2009). The monascus metabolite monacolin k reduces tumor progression and metastasis of lewis lung carcinoma cells. Journal of Agricultural and Food Chemistry, 57(18), 8258-8265. https://doi.org/10.1021/jf901619w

Hong, M. Y., Henning, S., Moro, A., Seeram, N. P., Zhang, Y., \& Heber, D. (2011). Chinese red yeast rice inhibition of prostate tumor growth in SCID mice. Cancer Prevention Research, 4(4), 608615. https://doi.org/10.1158/1940-6207.CAPR-10-0219

Hsu, W. H., \& Pan, T. M. (2012). Monascus purpureus-fermented products and oral cancer: A review. Applied Microbiology and Biotechnology, 93(5), 1831-1842. https://doi.org/10.1007/s00253012-3891-9

Ismaryani, A., Salni, S., Setiawan, A., \& Triwani, T. (2018). Effect of extract and Salung Leaf 
Fraction (Psychotria viridiflora Reinv. Ex. Blume) As Sitotoksit, Antiproliferation and Applose of Apoptosis on Cancer Cell of Serviks HeLa. Jurnal Ilmu Kefarmasian Indonesia, 16(2), 206. https://doi.org/10.35814/jifi.v16i2.528

Lee, C. I., Lee, C. L., Hwang, J. F., Lee, Y. H., \& Wang, J. J. (2013). Monascus-fermented red mold rice exhibits cytotoxic effect and induces apoptosis on human breast cancer cells. Applied Microbiology and Biotechnology, 97(3), 1269-1278. https://doi.org/10.1007/s00253-012-4279-6

Lestari, T. (2015). Penetapan kadar polifenol dan aktivitas antibakteri ekstrak etanol daun sintrong (Crassocephalum crepidiodes (Benth.) S. moore). Jurnal Kesehatan Bakti Tunas Husada: Jurnal Ilmu-Ilmu Keperawatan, Analis Kesehatan Dan Farmasi, 13(1), 107-112. https://doi.org/10.36465/jkbth.v13i1.20

Liu, D., \& Chen, Z. (2013). The effect of curcumin on breast cancer cells. Journal of Breast Cancer, 16(2), 133-137. https://doi.org/10.4048/jbc.2013.16.2.133

Mardany, M. P., Chrystomo, L. Y., \& Karim, A. K. (2016). Skrining Fitokimia dan Uji Aktivitas Sitotoksik dari Tumbuhan Sarang Semut ( Myrmecodia beccarii Hook . f .) Asal Kabupaten Merauke. Jurnal Biologi Papua, 8(1), 13-22.

Muaja. (2013). Analisis kandungan fitokimia dari uji toksisitas ekstrak metanol daun soyogik (Sauraula bracteosa DC) dengan menggunakan metode maserasi. Jurnal Ilmiah Sains, 13(2), 98. https://doi.org/10.35799/jis.13.2.2013.3052

Nijjar, P. S., Burke, F. M., Bloesch, A., \& Rader, D. J. (2010). Role of dietary supplements in lowering low-density lipoprotein cholesterol: A review. Journal of Clinical Lipidology, 4(4), 248-258. https://doi.org/10.1016/j.jacl.2010.07.001

Park, M. T., Kim, M. J., Kang, Y. H., Choi, S. Y., Lee, J. H., Choi, J. A., Kang, C. M., Cho, C. K., Kang, S., Bae, S., Lee, Y. S., Chung, H. Y., \& Lee, S. J. (2005). Phytosphingosine in combination with ionizing radiation enhances apoptotic cell death in radiation-resistant cancer cells through ROS-dependent and -independent AIF release. Blood, 105(4), 1724-1733. https://doi.org/10.1182/blood-2004-07-2938

Pattanagul, P., Pinthong, R., \& Phianmongkhol, A. (2007). Review of Angkak Production (Monascus purpureus). Chiang Mai J. Sci., 34(3), 319-328.

Pratiwi, L., Fudholi, A., Martien, R., \& Pramono, S. (2016). Ethanol Extract, Ethyl Acetate Extract, Ethyl Acetate Fraction, and n-Heksan Fraction Mangosteen Peels (Garcinia mangostana L.) As Source of Bioactive Substance Free-Radical Scavengers. JPSCR: Journal of Pharmaceutical Science and Clinical Research, 1(2), 71. https://doi.org/10.20961/jpscr.v1i2.1936

Priosoeryanto, B. P. (2009). Anti Proliferation.Pdf.

Priosoeryanto, B. P., Tateyama, S., Yamaguchi, R., \& Uchida, K. (1995). Establishment of a cell line (MCM-B2) from a benign mixed tumour of canine mammary gland. Research in Veterinary Science, 58(3), 272-276. https://doi.org/10.1016/0034-5288(95)90116-7

R. Hamidi, M., Jovanova, B., \& Kadifkova Panovska, T. (2014). Toxicological evaluation of the plant products using Brine Shrimp (Artemia salina L.) model. Macedonian Pharmaceutical Bulletin, 60(01), 9-18. https://doi.org/10.33320/maced.pharm.bull.2014.60.01.002

Rampe, M. J., \& Tombuku, J. L. (2015). Pengujian Fitokimia dan Toksisitas Ekstrak Etanol Jantung Pisang Kepok ( Musa paradisiaca LINN .) dengan Metode Brine Shrimp Lethality Test ( BSLT ). Jurnal Sainsmat, 4(2), 136-147.

Singgih, M., Saraswaty, V., Ratnaningrum, D., Priatni, S., \& Damayanti, S. (2014). The Influence of Temperature and Ethanol Concentration in Monacolin K Extraction from Monascus Fermented Rice. Procedia Chemistry, 9, 242-247. https://doi.org/10.1016/j.proche.2014.05.029

Talib, W. H., \& Mahasneh, A. M. (2010). Antiproliferative activity of plant extracts used against 
cancer in traditional medicine. Scientia Pharmaceutica, 78(1), 33-45.

https://doi.org/10.3797/scipharm.0912-11

Thorn, C. F., Oshiro, C., Marsh, S., Hernandez-Boussard, T., McLeod, H., Klein, T. E., \& Altman, R. B. (2011). Doxorubicin pathways. Pharmacogenetics and Genomics, 21(7), 440-446. https://doi.org/10.1097/fpc.0b013e32833ffb56

Vitalia, N., Najib, A., \& Ahmad, A. R. (2016). Uji toksisitas ekstrak daun pletekan (Ruellia tuberosa L.) dengan menggunakan metode brine shrimp lethality test (BSLT). Jurnal Fitofarmaka Indonesia, 3(1), 124-129. https://doi.org/10.33096/jffi.v3i1.171

Wei, W., Li, C., Wang, Y., Su, H., Zhu, J., \& Kritchevsky, D. (2003). Hypolipidemic and antiatherogenic effects of long-term Cholestin (Monascus purpureus-fermented rice, red yeast rice) in cholesterol fed rabbits. Journal of Nutritional Biochemistry, 14(6), 314-318. https://doi.org/10.1016/S0955-2863(03)00051-2

WHO. (n.d.). WHO $\mid$ Breast cancer.

Xu, B., Wang, Q., \& Sung, C. (2017). Telomerase inhibitory effects of red pigment rubropunctatin and statin monacolin 1 isolated from red yeast rice. Genes, 8(5). https://doi.org/10.3390/genes8050129

Yang, T., Liu, J., Luo, F., Lin, Q., Rosol, T. J., \& Deng, X. (2014). Anticancer properties of Monascus metabolites. Anticancer Drugs, 25(7), 735-744. https://doi.org/10.1097/CAD.0000000000000102

Yun, U. J., Lee, J. H., Shim, J., Yoon, K., Goh, S. H., Yi, E. H., Ye, S. K., Lee, J. S., Lee, H., Park, J., Lee, I. H., \& Kim, Y. N. (2019). Anticancer effect of doxorubicin is mediated by downregulation of HMG-Co A reductase via inhibition of EGFR/Src pathway. Laboratory Investigation, 99(8), 1157-1172. https://doi.org/10.1038/s41374-019-0193-1

Zhang, Z., Ali, Z., Khan, S. I., \& Khan, I. A. (2016). Cytotoxic monacolins from red yeast rice, a Chinese medicine and food. Food Chemistry, 202, 262-268. https://doi.org/10.1016/j.foodchem.2015.12.039

Zheng, Y., Xin, Y., Shi, X., \& Guo, Y. (2010). Anticancer effect of rubropunctatin against human gastric carcinoma cells BGC-823. Applied Microbiology and Biotechnology, 88(5), 1169-1177. https://doi.org/10.1007/s00253-010-2834-6 